\title{
Association between consumption of vegetables and COVID-19 mortality at a country level in Europe
}

Susana C Fonseca (1), loar Rivas (2), Dora Romaguera (2), Marcos Quijal-Zamorano (2), Wienczyslawa Czarlewski (3, 4), Alain Vidal (5), Joao A Fonseca (6), Joan Ballester (2), Josep M Anto (2, 7-9), Xavier Basagana $(2,8,9)$, Luis M Cunha (1), Jean Bousquet(10, 11)

1. GreenUPorto - Sustainable Agrifood Production Research Centre, DGAOT, Faculty of Sciences, University of Porto, Campus de Vairão, Rua da Agrária, Porto, Portugal.

2. ISGlobAL, Barcelona Institute for Global Health, Barcelona, Spain.

3. Medical Consulting Czarlewski, Levallois, France.

4. MASK-air, Montpellier, France.

5. World Business Council for Sustainable Development (WBCSD), Maison de la Paix, Geneva, Switzerland \& AgroParisTech - Paris Institute of Technology for Life, Food and Environmental Sciences, Paris, France.

6. CINTESIS, Center for Research in Health Technology and Information Systems, Faculdade de Medicina da Universidade do Porto; and Medida, Lda Porto, Portugal

7. IMIM (Hospital del Mar Research Institute), Barcelona, Spain.

8. Universitat Pompeu Fabra (UPF), Barcelona, Spain.

9. CIBER Epidemiología y Salud Pública (CIBERESP), Barcelona, Spain.

10. Charité, Universitätsmedizin Berlin, Humboldt-Universität zu Berlin, and Berlin Institute of Health, Comprehensive Allergy Center, Department of Dermatology and Allergy, Berlin, Germany.

11. MACVIA-France, Montpellier, France.

12. Health Research Institute of the Balearic Islands (IdISBa), Palma de Mallorca, Spain.

13. CIBER Physiopathology of Obesity and Nutrition (CIBEOBN), Madrid, Spain.

Short title: Brassica vegetables and COVID-19

Address for correspondance: Professor Jean Bousquet

273 avenue d'Occitanie, 34090 Montpellier, France Tel +33 6114288 47, Fax +33 467416701 jean.bousquet@orange.fr 


\section{Abstract}

\section{Background}

Many foods have an antioxidant activity, and nutrition may mitigate COVID-19. To test the potential role of vegetables in COVID-19 mortality in Europe, we performed an ecological study.

\section{Methods}

The European Food Safety Authority (EFSA) Comprehensive European Food Consumption Database was used to study the country consumption of Brassica vegetables (broccoli, cauliflower, head cabbage (white, red and savoy cabbage), leafy brassica) and to compare them with spinach, cucumber, courgette, lettuce and tomato. The COVID-19 mortality per number of inhabitants was obtained from the Johns Hopkins Coronavirus Resource Center. EuroStat data were used for potential confounders at the country level including Gross Domestic Product (GDP) (2019), population density (2018), percentage of people over 64 years (2019), unemployment rate (2019) and percentage of obesity (2014, to avoid missing values). Mortality counts were analyzed with quasi-Poisson regression models to model the death rate while accounting for over-dispersion.

\section{Results}

Of all the variables considered, including confounders, only head cabbage and cucumber reached statistical significance with the COVID-19 death rate per country. For each g/day increase in the average national consumption of some of the vegetables (head cabbage and cucumber), the mortality risk for COVID-19 decreased by a factor of 11, down to $13.6 \%$. Lettuce consumption increased COVID-19 mortality. The adjustment did not change the point estimate and the results were still significant.

\section{Discussion}

The negative ecological association between COVID-19 mortality and the consumption of cabbage and cucumber supports the a priori hypothesis previously reported. The hypothesis needs to be tested in individual studies performed in countries where the consumption of vegetables is common.

Key words: COVID-19, country, Brassica vegetables, death rates 


\section{Introduction}

One of the striking problems raised by the COVID-19 pandemic is the highly variable death rate between and within countries ${ }^{1}$. The COVID-19 epidemic is multifactorial but, among potentially relevant factors, diet has received little attention. Many foods have an antioxidant activity ${ }^{2-4}$ and it has been proposed that the role of nutrition may mitigate COVID-19 ${ }^{5}$. Some countries with low COVID19 mortality rates appear to be those with a relatively high consumption of traditional foods, many of which are fermented ${ }^{1}$. It was proposed that this was associated with the antioxidant activity of the foods acting on insulin resistance ${ }^{1}$.

The European Food Safety Authority (EFSA) Comprehensive European Food Consumption Database was used to study the country consumption of fermented vegetables, pickled/marinated vegetables, fermented milk, yoghurt and fermented sour milk. The negative ecological association between COVID-19 mortality and the consumption of fermented vegetables ${ }^{6}$ supported the $a$ priori hypothesis previously reported ${ }^{1}$. In this hypothesis, we proposed that vegetables such as Brassica - with an antioxidant activity reducing insulin resistance - may also be associated with low COVID-19 mortality in countries.

To test the potential role of Brassica and some other antioxidant vegetables in the COVID-19 mortality in Europe, we performed an ecological study with Brassica vegetables (broccoli, cauliflower, head cabbage (white, red and savoy cabbage), leafy brassica) and compared them with spinach, cucumber, courgette, lettuce and tomato.

\section{Methods}

\section{Selection of the database}

The European Union provided the European Food Safety Authority (EFSA) Comprehensive European Food Consumption Database in 2011 as well as an update in 2015 as previously proposed.

\section{Selection of foods}

The hypothesis raised recently proposed that diet with Brassica vegetables may explain some of the differences in the COVID-19 death rates between countries. We then selected broccoli, cauliflower, head cabbage (white, red and savoy cabbage), leafy brassica, spinach, cucumber, courgette, lettuce, and tomato as a control.

Data from the national surveys of different EU countries have been extracted from the EFSA Comprehensive European Food Consumption Database for different vegetables (Tables 1 and 2). 


\section{Assessment of COVID-19 mortality}

We used mortality per number of inhabitants to assess the death rates as proposed by the European Center for Disease Prevention and Control (ecdc, https://www.ecdc.europa.eu/en). Raw data were used for the Poisson analysis.

Data on COVID-19 mortality were downloaded from the Johns Hopkins Coronavirus Resource Center (https://coronavirus.jhu.edu) on June $22^{\text {nd }}, 2020$. In addition, we downloaded data from EuroStat on: Gross Domestic Product (GDP) of the country (2019), population density (2018), percentage of people older than 64 years (2019), unemployment rate (2019) and percentage of obesity (2014, to avoid missing values).

\section{Statistical analysis}

Mortality counts were analyzed with quasi-Poisson regression models - with log of population as an offset - to model the death rate while accounting for over-dispersion. Models were fitted separately for each of the food consumption groups. Due to the small number of countries included in the analyses, we adjusted our models using the first principal component of a principal component analysis (PCA) of the variables GDP, population density, percentage of people older than 64 years, unemployment and obesity ${ }^{7}$. Adjustment was repeated using the variable most associated with mortality among the confounders, instead of using the principal component.

\section{Results}

\section{Food intake in European countries}

The intake of selected foods was given in g/day (Figure 2). For some of the foods, over $20 \mathrm{~g} / \mathrm{day}$ are consumed in certain countries (head cabbage, lettuce, tomato, courgette and cucumber) whereas, for the others, less than $10 \mathrm{~g} / \mathrm{day}$ are consumed (leafy Brassica, cauliflower, broccoli and spinach) (Figure 2).

\section{Association between COVID-19 mortality and food intake at the country level}

Of all the variables considered, including confounders, only head cabbage and cucumber reached statistical significance in their association with the COVID-19 death rate per country, regardless of the adjustment. (Table 3 and Figures 1 and 2). 
After adjusting for potential confounders, for each g/day increase in consumption of head cabbage of the country, the mortality risk for COVID-19 decreases by $13.6 \%$. For each g/day increase in consumption of cucumber, the mortality risk decreases by $15.7 \%$. Consumption of lettuce and broccoli showed the opposite pattern, i.e. a higher consumption was associated with a higher COVID-19 mortality. However, the results were more sensitive to adjustment, and the associations were no longer significant in some of the models.

\section{Discussion}

This study shows that in countries where head cabbage and cucumber are highly consumed, death rates are low. On the other hand, there was no statistical significance on percentage change (p-value > 0.05 ) except for lettuce consumption and broccoli that were associated with an increased death rate only in some of the models.

\section{Limitations}

According to the Johns Hopkins coronavirus resource center (https://coronavirus.jhu.edu), one of the most important ways of measuring the burden of COVID-19 is mortality. However, death rates are assessed differently between countries and there are many biases that are almost impossible to control

${ }^{1}$. Using the rate of COVID-19 confirmed cases is subject to limitations. Differences in the mortality rates depend on the characteristics of the health care system, the reporting method, whether or not deaths outside the hospital have been counted and other factors, many of which remain unknown. Countries throughout the world have reported very different case fatality ratios - the number of deaths divided by the number of confirmed cases - but these numbers cannot be compared easily due to biases.

It is very important to consider differences in food consumption within countries but this cannot be studied using the EFSA database. As found in France, Spain and Italy, there are large regional differences in death rates and it would be of interest to compare sub-national regions with the different consumptions of fermented foods ${ }^{1}$.

The consumption of vegetables is likely to show a seasonal pattern which may differ among countries. Our analysis used annual average consumption and a seasonal bias cannot be excluded.

A limited number of countries have been studied due to the lack of information on food consumption. A definite conclusion can therefore not be made. The selection of confounding factors has been arbitrary and more studies are needed. As in any ecological study, any inference from the observed association should be made at the country level, as the possibility of ecological fallacy precludes 
inferences at the individual level. Further testing in properly designed individual studies would be of interest.

Moreover, associations do not mean causality, and patterns of food consumption can be a proxy for other undetermined factors.

Understanding the multiple factors that are likely to explain inter and intra-national geographical variations will not be possible until indicators of the pandemic distribution have been improved and properly-designed studies conducted. However, this study is of interest since it is the first to attempt to link death rates with food consumption at a country level.

\section{Interpretation}

COVID-19, like most diseases, exhibits large geographical variations which frequently remain unexplained despite abundant research ${ }^{8}$. Though the more relevant factors are likely to be related to intensity and timing of interventions ${ }^{9}$, demographic factors, seasonal variations, immunity, and crossimmunity, other factors like environment or nutrition should not be overlooked. Our study suggests that European countries with a lower COVID-19 mortality are more likely to exhibit a large consumption of head cabbage and cucumber.

Though our results do not allow to infer causality, they do reinforce our a priory hypothesis that the ingestion of anti-oxidant foods acting on insulin intolerance may have reduced the severity of COVID19 and are in line with recent data on fermented foods ${ }^{6}$. A large number of vegetables have an antioxidant activity and are effective in cardiovascular diseases ${ }^{10}$ or diabetes ${ }^{11}$. Antioxidants include mono- and polyunsaturated fatty acids, omega-3 fatty acids, antioxidant vitamins, minerals, phytochemicals, fiber, and plant protein ${ }^{12}$.

Several foods can interact with transcription factors related to antioxidant effects such as Nrf2 ${ }^{13,14}$. Natural compounds derived from vegetables such as curcumin, sulforaphane, resveratrol and vitamin D, among others, can activate Nrf ${ }^{15}$. Cruciferous vegetables like Brassicaceae contain high amounts of sulforaphane, a potent activator of Nfr2 ${ }^{16}$. However, broccoli ${ }^{17-19}$ and cauliflower ${ }^{20}$ have a potent anti-oxidant activity, but, in the present study, their consumption is not associated with differences in COVID-19 death rates between countries. It is possible that the amount ingested is too low to provide any protection. The other hypothesis that comes to mind here is that broccoli and cauliflower could be consumed cooked more often than raw ${ }^{21}$. It should be noted that cucumber and head cabbage are reducing death rates for a consumption of over $10 \mathrm{~g} / \mathrm{day}$, whereas broccoli, leafy brassica and cauliflower are ingested at a dose of under $6 \mathrm{~g} / \mathrm{day}$. It is therefore possible that broccoli may have some effect at the individual level. Cucumber does not belong to the Brassicacea family but did however show a protective effect. Although less well studied, cucumber acts as an antioxidant on 
insulin resistance and its related diseases ${ }^{22-24}$. Cucurbitacin B, a natural compound that exists in edible plants (bitter melons, cucumbers, pumpkins and zucchini), has anti-inflammatory and hypoglycemic properties through the activation of Nrf $2^{25,26}$. These results and those of the recent study on fermented foods suggest a strong link between Nrf2 and the protection against severe forms of COVID-19.

The antioxidant effect of tomatoes or lettuce may be related to Nrf2, and, in the present study, may not be involved in the prevention of COVID-19 deaths. On the other hand, lettuce appears to increase death rates for unclear reasons.

Our study was restricted to European countries, so its results cannot be extrapolated to other regions. Thus, although this study is only indicative of the role of diet in COVID-19, it is however another piece of the hypothesis proposing that some vegetables with antioxidant properties may be involved in the prevention of severe COVID-19 at a country level. 


\section{References}

1. Bousquet J, Anto J, Iaccarino G, et al. Is diet partly responsible for differences in Covid-19 death rates between and within countries? Clin Transl Allergy 2020.

2. Jain S, Buttar HS, Chintameneni M, Kaur G. Prevention of Cardiovascular Diseases with AntiInflammatory and Anti- Oxidant Nutraceuticals and Herbal Products: An Overview of PreClinical and Clinical Studies. Recent Pat Inflamm Allergy Drug Discov 2018;12:145-57.

3. Razmpoosh E, Javadi M, Ejtahed HS, Mirmiran P. Probiotics as beneficial agents in the management of diabetes mellitus: a systematic review. Diabetes Metab Res Rev 2016;32:143-68.

4. Serino A, Salazar G. Protective Role of Polyphenols against Vascular Inflammation, Aging and Cardiovascular Disease. Nutrients 2018;11.

5. Zabetakis I, Lordan R, Norton C, Tsoupras A. COVID-19: The Inflammation Link and the Role of Nutrition in Potential Mitigation. Nutrients 2020;12.

6. Fonseca S, Rivas I, Romaguera D, et al. Association between consumption of fermented vegetables and COVID-19 mortality at a country level in Europe MEDRXIV/2020/147025 2020.

7. Ver Hoef JM, Boveng PL. Quasi-Poisson vs. negative binomial regression: how should we model overdispersed count data? Ecology 2007;88:2766-72.

8. Sunyer J, Jarvis D, Pekkanen J, et al. Geographic variations in the effect of atopy on asthma in the European Community Respiratory Health Study. J Allergy Clin Immunol 2004;114:1033-9.

9. Kissler SM, Tedijanto C, Goldstein E, Grad YH, Lipsitch M. Projecting the transmission dynamics of SARS-CoV-2 through the postpandemic period. Science 2020.

10. Tang GY, Meng X, Li Y, Zhao CN, Liu Q, Li HB. Effects of Vegetables on Cardiovascular Diseases and Related Mechanisms. Nutrients 2017;9.

11. Alkhatib A, Tsang C, Tiss A, et al. Functional Foods and Lifestyle Approaches for Diabetes Prevention and Management. Nutrients 2017;9.

12. Patel H, Chandra S, Alexander S, Soble J, Williams KA, Sr. Plant-Based Nutrition: An Essential Component of Cardiovascular Disease Prevention and Management. Curr Cardiol Rep 2017;19:104.

13. Pall ML, Levine S. Nrf2, a master regulator of detoxification and also antioxidant, antiinflammatory and other cytoprotective mechanisms, is raised by health promoting factors. Sheng Li Xue Bao 2015;67:1-18.

14. Iddir M, Brito A, Dingeo G, et al. Strengthening the Immune System and Reducing Inflammation and Oxidative Stress through Diet and Nutrition: Considerations during the COVID-19 Crisis. Nutrients 2020;12.

15. Jimenez-Osorio AS, Gonzalez-Reyes S, Pedraza-Chaverri J. Natural Nrf2 activators in diabetes. Clin Chim Acta 2015;448:182-92.

16. Bai Y, Wang X, Zhao S, Ma C, Cui J, Zheng Y. Sulforaphane Protects against Cardiovascular Disease via Nrf2 Activation. Oxid Med Cell Longev 2015;2015:407580.

17. Dang Y, Zhou T, Hao L, Cao J, Sun Y, Pan D. In Vitro and in Vivo Studies on the AngiotensinConverting Enzyme Inhibitory Activity Peptides Isolated from Broccoli Protein Hydrolysate. J Agric Food Chem 2019;67:6757-64.

18. Fahey JW, Wade KL, Stephenson KK, et al. Bioavailability of Sulforaphane Following Ingestion of Glucoraphanin-Rich Broccoli Sprout and Seed Extracts with Active Myrosinase: A Pilot Study of the Effects of Proton Pump Inhibitor Administration. Nutrients 2019;11.

19. Vanduchova A, Anzenbacher P, Anzenbacherova E. Isothiocyanate from Broccoli, Sulforaphane, and Its Properties. J Med Food 2019;22:121-6.

20. Larocca M, Perna AM, Simonetti A, et al. Antioxidant and anti-inflammatory effects of cauliflower leaf powder-enriched diet against LPS induced toxicity in rabbits. Food Funct 2017;8:3288-96.

21. Baenas N, Marhuenda J, Garcia-Viguera C, Zafrilla P, Moreno DA. Influence of Cooking Methods on Glucosinolates and Isothiocyanates Content in Novel Cruciferous Foods. Foods $2019 ; 8$. 
medRxiv preprint doi: https://doi.org/10.1101/2020.07.17.20155846; this version posted July 18, 2020. The copyright holder for this preprint

(which was not certified by peer review) is the author/funder, who has granted medRxiv a license to display the preprint in perpetuity.

All rights reserved. No reuse allowed without permission.

22. Dixit Y, Kar A. Protective role of three vegetable peels in alloxan induced diabetes mellitus in male mice. Plant Foods Hum Nutr 2010;65:284-9.

23. Heidari H, Kamalinejad M, Noubarani M, et al. Protective mechanisms of Cucumis sativus in diabetes-related modelsof oxidative stress and carbonyl stress. Bioimpacts 2016;6:33-9.

24. Marisol MM, Celeste TM, Laura MM, et al. Effect of Cucumis sativus on Dysfunctional 3T3-L1 Adipocytes. Sci Rep 2019;9:13372.

25. Kim KH, Lee IS, Park JY, Kim Y, An EJ, Jang HJ. Cucurbitacin B Induces Hypoglycemic Effect in Diabetic Mice by Regulation of AMP-Activated Protein Kinase Alpha and Glucagon-Like Peptide-1 via Bitter Taste Receptor Signaling. Front Pharmacol 2018;9:1071.

26. Kim M, Park SY, Jin ML, Park G, Son HJ. Cucurbitacin B inhibits immunomodulatory function and the inflammatory response in macrophages. Immunopharmacol Immunotoxicol 2015;37:47380 . 
medRxiv preprint doi: https://doi.org/10.1101/2020.07.17.20155846; this version posted July 18, 2020. The copyright holder for this preprint (which was not certified by peer review) is the author/funder, who has granted medRxiv a license to display the preprint in perpetuity.

All rights reserved. No reuse allowed without permission.

Table 1: Foods tested (EFSA database)

\begin{tabular}{|c|c|c|c|c|c|c|c|}
\hline $\begin{array}{l}\text { Exposure } \\
\text { hierarchy (L1) }\end{array}$ & $\begin{array}{l}\text { Exposure } \\
\text { hierarchy (L2) }\end{array}$ & $\begin{array}{l}\text { Exposure } \\
\text { hierarchy (L3) }\end{array}$ & $\begin{array}{l}\text { Exposure } \\
\text { hierarchy (L4) }\end{array}$ & $\begin{array}{l}\text { Exposure } \\
\text { hierarchy (L5) }\end{array}$ & $\begin{array}{l}\text { Exposure } \\
\text { hierarchy (L6) }\end{array}$ & $\begin{array}{c}\mathrm{N} \\
\text { countries }\end{array}$ & $\begin{array}{c}\text { N } \\
\text { subjects }\end{array}$ \\
\hline \multirow{9}{*}{$\begin{array}{l}\text { Vegetables and } \\
\text { vegetable } \\
\text { products }\end{array}$} & \multirow{2}{*}{$\begin{array}{l}\text { Flowering } \\
\text { brassica }\end{array}$} & Broccoli & - & - & - & 22 & 40143 \\
\hline & & Cauliflower & - & - & - & 22 & 40143 \\
\hline & \multirow{4}{*}{$\begin{array}{l}\text { Leafy } \\
\text { vegetables }\end{array}$} & Leafy brassica & - & - & - & 19 & 38357 \\
\hline & & Head brassica & Head cabbage & - & - & 22 & 40143 \\
\hline & & Lettuces and salad plants & Lettuce & - & - & 22 & 40143 \\
\hline & & Spinach-type leaves & Spinach and similar & Spinach & - & 22 & 40143 \\
\hline & \multirow{3}{*}{$\begin{array}{l}\text { Fruiting } \\
\text { vegetables }\end{array}$} & Solanacea & Tomatoes and similar & Tomatoes & - & 18 & 34152 \\
\hline & & Cucurbits fruiting & Cucurbits with edible & Courgettes and similar & Courgettes & 19 & 34850 \\
\hline & & vegetables & peel & Cucumbers and similar & Cucumbers & 22 & 40143 \\
\hline
\end{tabular}


medRxiv preprint doi: https://doi.org/10.1101/2020.07.17.20155846; this version posted July 18, 2020. The copyright holder for this preprint (which was not certified by peer review) is the author/funder, who has granted medRxiv a license to display the preprint in perpetuity. All rights reserved. No reuse allowed without permission.

Table 2: Origin (survey and year) of consumption data obtained from the EFSA Comprehensive European Food Consumption database

\begin{tabular}{|c|c|c|c|c|c|c|c|c|c|c|c|}
\hline Country & Year & Survey name & 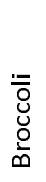 & 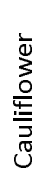 & $\begin{array}{l}\frac{\pi}{U} \\
\frac{\pi}{N} \\
\frac{\pi}{0} \\
0 \\
\frac{\mathbb{Z}}{\pi} \\
\mathbb{1}\end{array}$ & 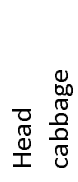 & 岂 & 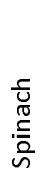 & $\begin{array}{l}\mathscr{d} \\
\stackrel{0}{0} \\
\stackrel{+}{\sigma} \\
\stackrel{E}{0}\end{array}$ & 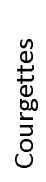 & 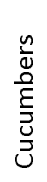 \\
\hline Austria & 2014 & AT-NATIONAL-2016 & + & + & + & + & + & + & + & + & + \\
\hline Belgium & 2014 & NATIONAL-FCS-2014 & + & + & + & + & + & + & + & + & + \\
\hline Croatia & 2011 & NIPNOP-HAH-2011-2012 & + & + & + & + & + & + & & + & + \\
\hline Cyprus & 2014 & CY 2014-2017-LOT2 & + & + & & + & + & + & + & + & + \\
\hline Czech Republic & 2003 & SISP04 & + & + & + & + & + & + & + & + & + \\
\hline Denmark & 2005 & DANSDA 2005-08 & + & + & + & + & + & + & + & & + \\
\hline Estonia & 2013 & DIET-2014-EST-A & + & + & + & + & + & + & + & & + \\
\hline Finland & 2012 & FINDIET2012 & + & + & + & + & + & + & & + & + \\
\hline France & 2014 & INCA3 & + & + & + & + & + & + & + & + & + \\
\hline Germany & 2007 & NATIONAL NUTRITION SURVEY II & + & + & + & + & + & + & + & + & + \\
\hline Greece & 2014 & GR-EFSA-LOT2 2014-2015 & + & + & & + & + & + & + & + & + \\
\hline Hungary & 2003 & NATIONAL REPR SURV & + & + & + & + & + & + & + & + & + \\
\hline Ireland & 2008 & NANS 2012 & + & + & + & + & + & + & + & + & + \\
\hline Italy & 2005 & INRAN SCAI 2005-06 & + & + & + & + & + & + & + & + & + \\
\hline Latvia & 2012 & LATVIA_2014 & + & + & + & + & + & + & + & + & + \\
\hline Netherlands & 2012 & FCS2016_CORE & + & + & + & + & + & + & + & + & + \\
\hline Portugal & 2015 & IAN.AF 2015-2016 & + & + & + & + & + & + & + & + & + \\
\hline Romania & 2012 & DIETA PILOT ADULTS & + & + & & + & + & + & + & + & + \\
\hline Slovenia & 2017 & SI.MENU-2018 & + & + & + & + & + & + & + & + & + \\
\hline Spain & 2013 & ENALIA2 & + & + & + & + & + & + & + & + & + \\
\hline Sweden & 2010 & RIKSMATEN 2010 & + & + & + & + & + & + & & & + \\
\hline United Kingdom & 2008 & NDNS ROLLING PROGRAMME YEARS 1-3 & + & + & + & + & + & + & & + & + \\
\hline
\end{tabular}


medRxiv preprint doi: https://doi.org/10.1101/2020.07.17.20155846; this version posted July 18, 2020. The copyright holder for this preprint (which was not certified by peer review) is the author/funder, who has granted medRxiv a license to display the preprint in perpetuity. All rights reserved. No reuse allowed without permission.

Table 3.: Percent change in COVID-19 death risk (with 95\% confidence intervals $(\mathrm{Cl})$ ) as a function of diet variables. Estimations for each diet variable come from a different model.

\begin{tabular}{|c|c|c|c|c|c|c|}
\hline \multirow[b]{2}{*}{ Vegetable } & \multicolumn{2}{|l|}{ Crude } & \multicolumn{2}{|c|}{ Adjusted $^{\mathrm{a}}$} & \multicolumn{2}{|l|}{ Adjusted $^{\mathrm{b}}$} \\
\hline & $\begin{array}{l}\text { Percent change } \\
\quad(95 \% \mathrm{Cl})\end{array}$ & $p$-value & $\begin{array}{l}\text { Percent change } \\
(95 \% \mathrm{Cl})\end{array}$ & $\mathrm{p}$-value & $\begin{array}{l}\text { Percent change } \\
(95 \% \mathrm{Cl})\end{array}$ & $p$-value \\
\hline Head cabbage & $-13.0(-22.3,-2.5)$ & 0.027 & $-13.6(-23.7,-2.1)$ & 0.034 & $-11.4(-20.7,-1.0)$ & 0.046 \\
\hline Leafy brassica & $4.6(-14.5,28.0)$ & 0.669 & $5.0(-15.6,30.6)$ & 0.668 & $-2.8(-22.1,21.2)$ & 0.804 \\
\hline Lettuce & $3.7(0.7,6.9)$ & 0.026 & $6.0(2.3,9.8)$ & 0.004 & $4.5(-1.4,10.8)$ & 0.152 \\
\hline Tomatoes & $0.4(-1.4,2.3)$ & 0.656 & $0.3(-1.6,2.3)$ & 0.732 & $-0.0(-1.4,1.4)$ & 0.988 \\
\hline Courgettes & $1.7(-1.8,5.4)$ & 0.357 & $2.1(-1.7,6.0)$ & 0.307 & $1.0(-2.6,4.8)$ & 0.594 \\
\hline Cucumber & $-11.5(-17.4,-5.1)$ & 0.003 & $-15.7(-22.1,-8.8)$ & 0.000 & $-11.5(-18.9,-3.5)$ & 0.012 \\
\hline Broccoli & $8.9(-2.3,21.3)$ & 0.138 & $11.5(-2.4,27.4)$ & 0.125 & $16.4(4.8,29.3)$ & 0.010 \\
\hline Spinach & $5.1(-3.7,14.8)$ & 0.277 & $5.6(-3.6,15.6)$ & 0.260 & $2.2(-7.3,12.6)$ & 0.670 \\
\hline Cauliflower & $-5.2(-28.7,26.2)$ & 0.720 & $-10.3(-36.6,26.9)$ & 0.545 & $10.0(-21.2,53.3)$ & 0.583 \\
\hline
\end{tabular}

${ }^{a}$ adjusted for the first principal component of a principal component analysis that included the variables: GDP, population density, percent of population over 64 years, percent of obesity and percent of unemployment.

${ }^{b}$ adjusted for unemployment, which was the strongest predictor a mong the confounders in single variable models $(p=0.06)$. 
medRxiv preprint doi: https://doi.org/10.1101/2020.07.17.20155846; this version posted July 18, 2020. The copyright holder for this preprint (which was not certified by peer review) is the author/funder, who has granted medRxiv a license to display the preprint in perpetuity.

All rights reserved. No reuse allowed without permission.

\section{Figure 1: Consumption of different foods in Europe}

Figure 2. Raw data and estimated relationship between country death rates for COVID-19 and consumption of vegetables ( $\mathrm{g} / \mathrm{day}$ ) using the quasi-Poisson regression model 


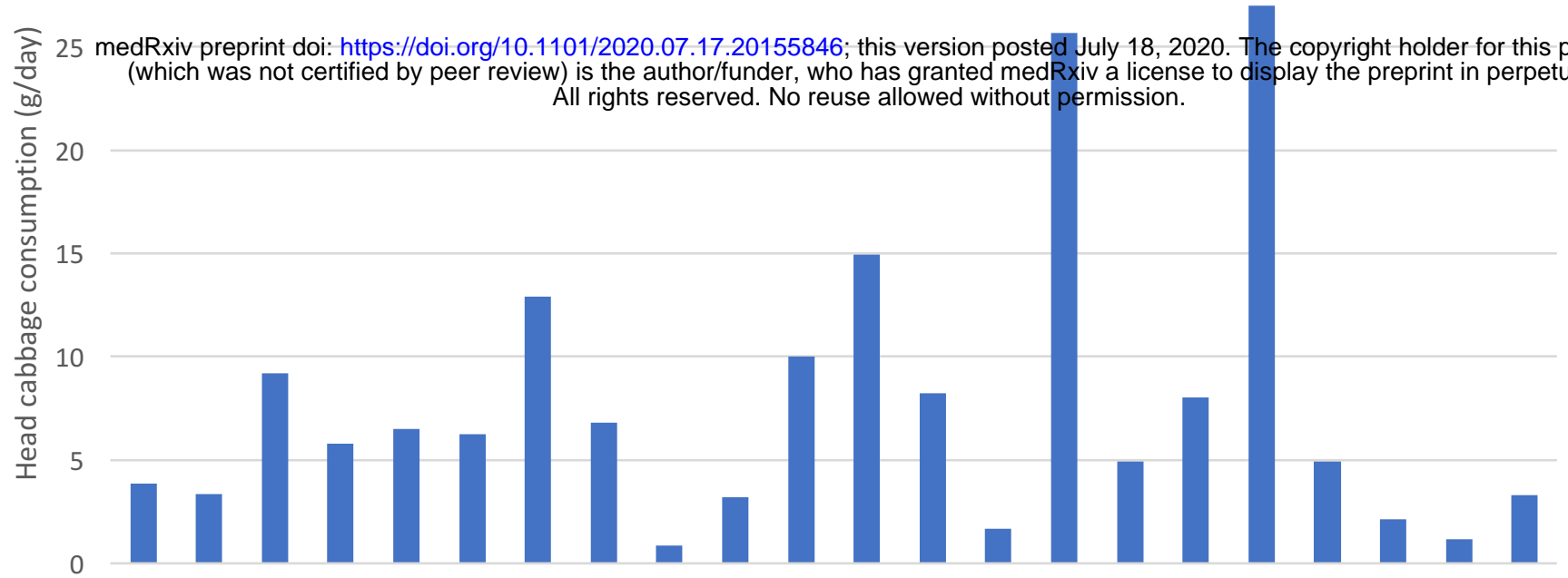

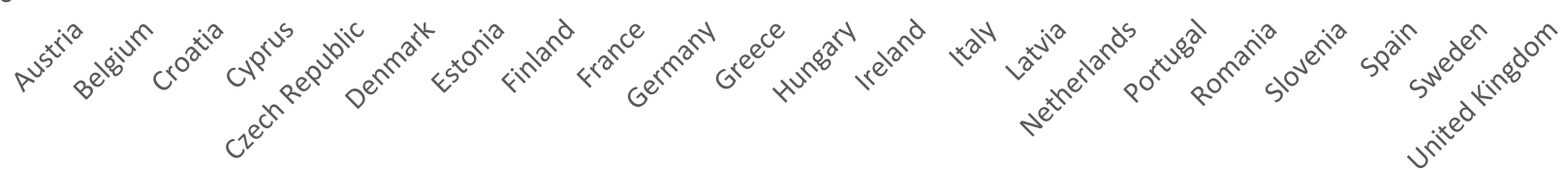

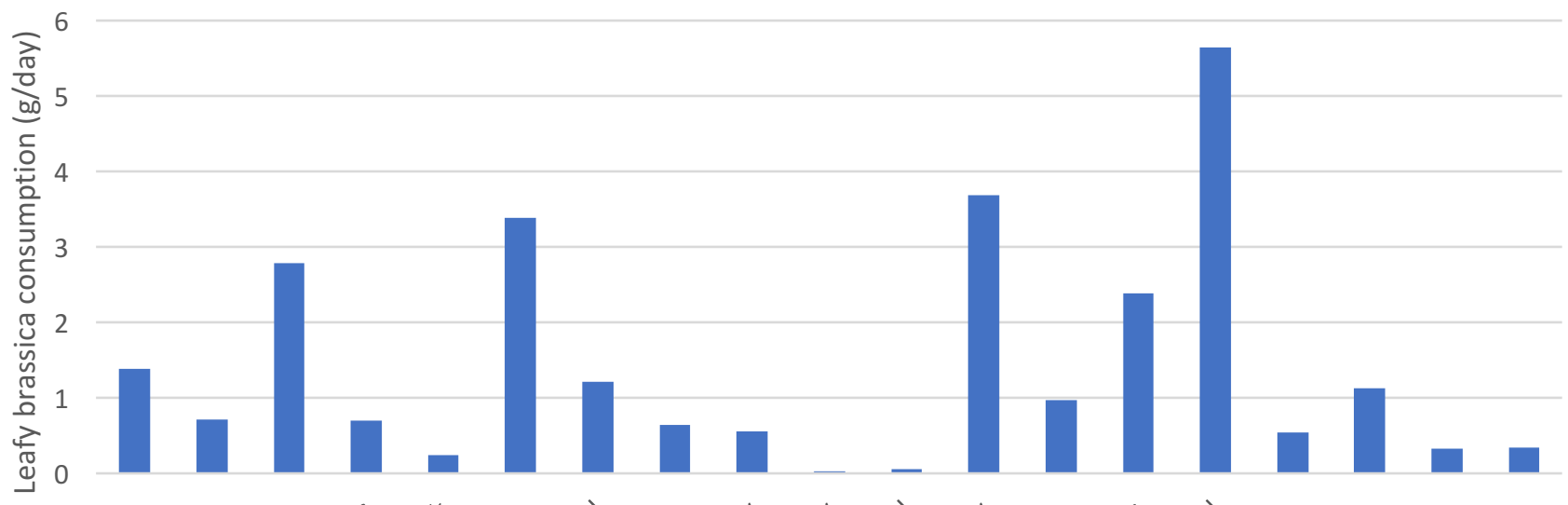

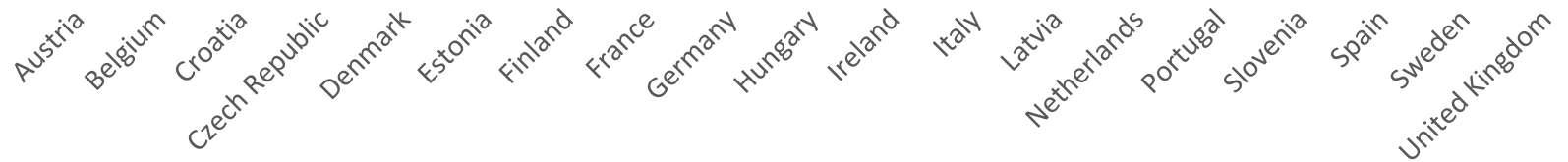

30

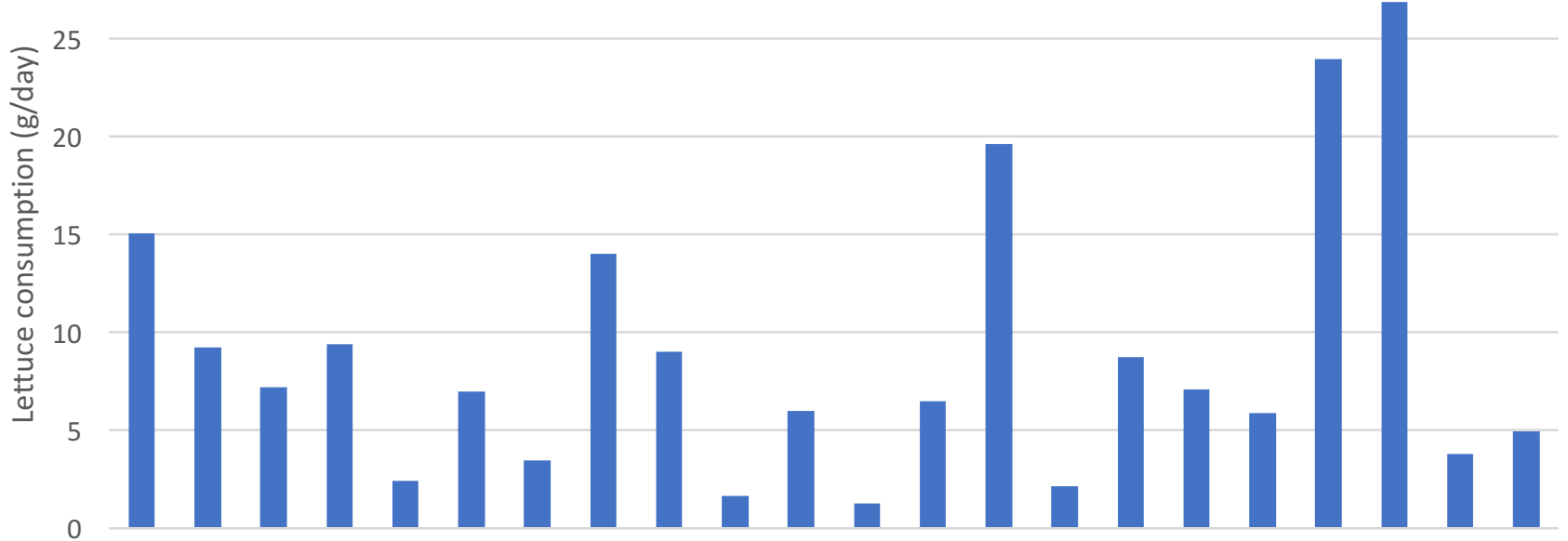

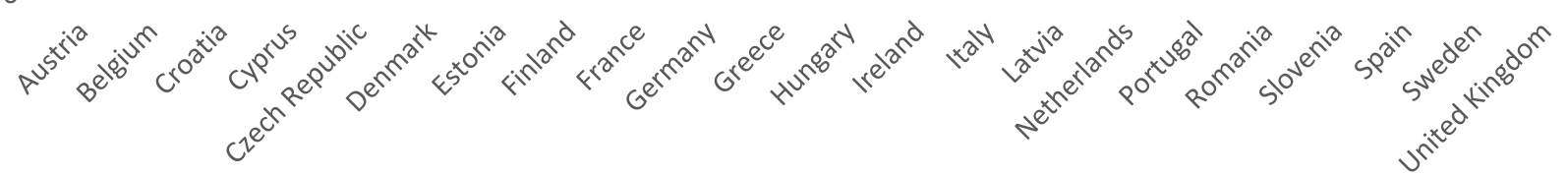


med ( (Wowicb was not certified by peer review) is the author/funder, who has granted medRxiv a license to display the preprint in perpetuity.

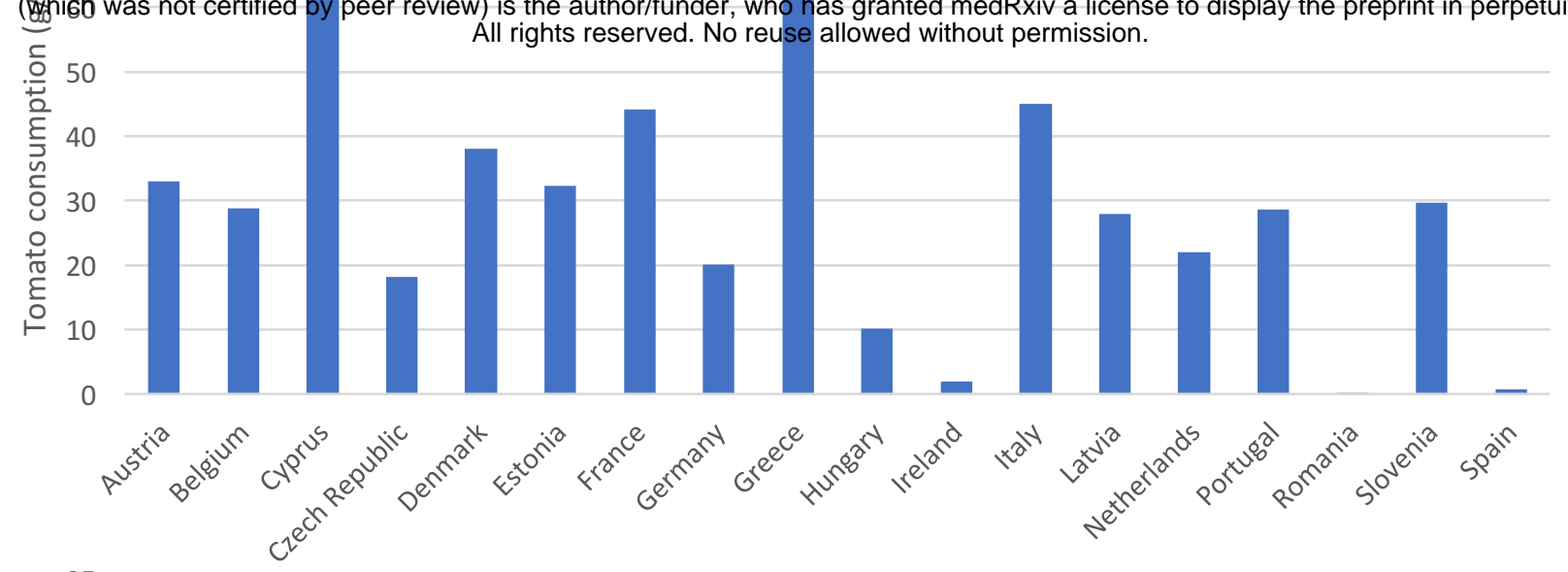

25
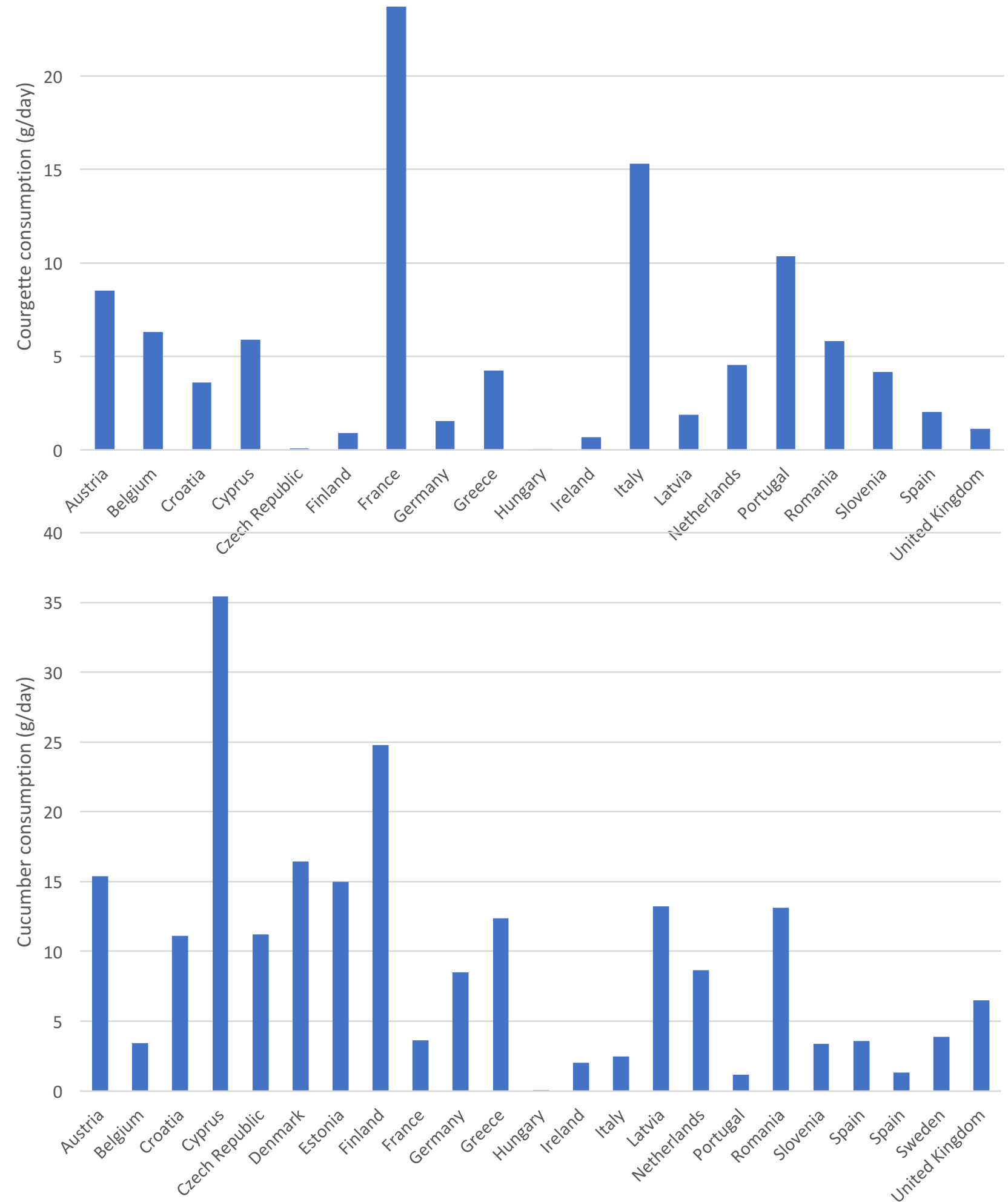

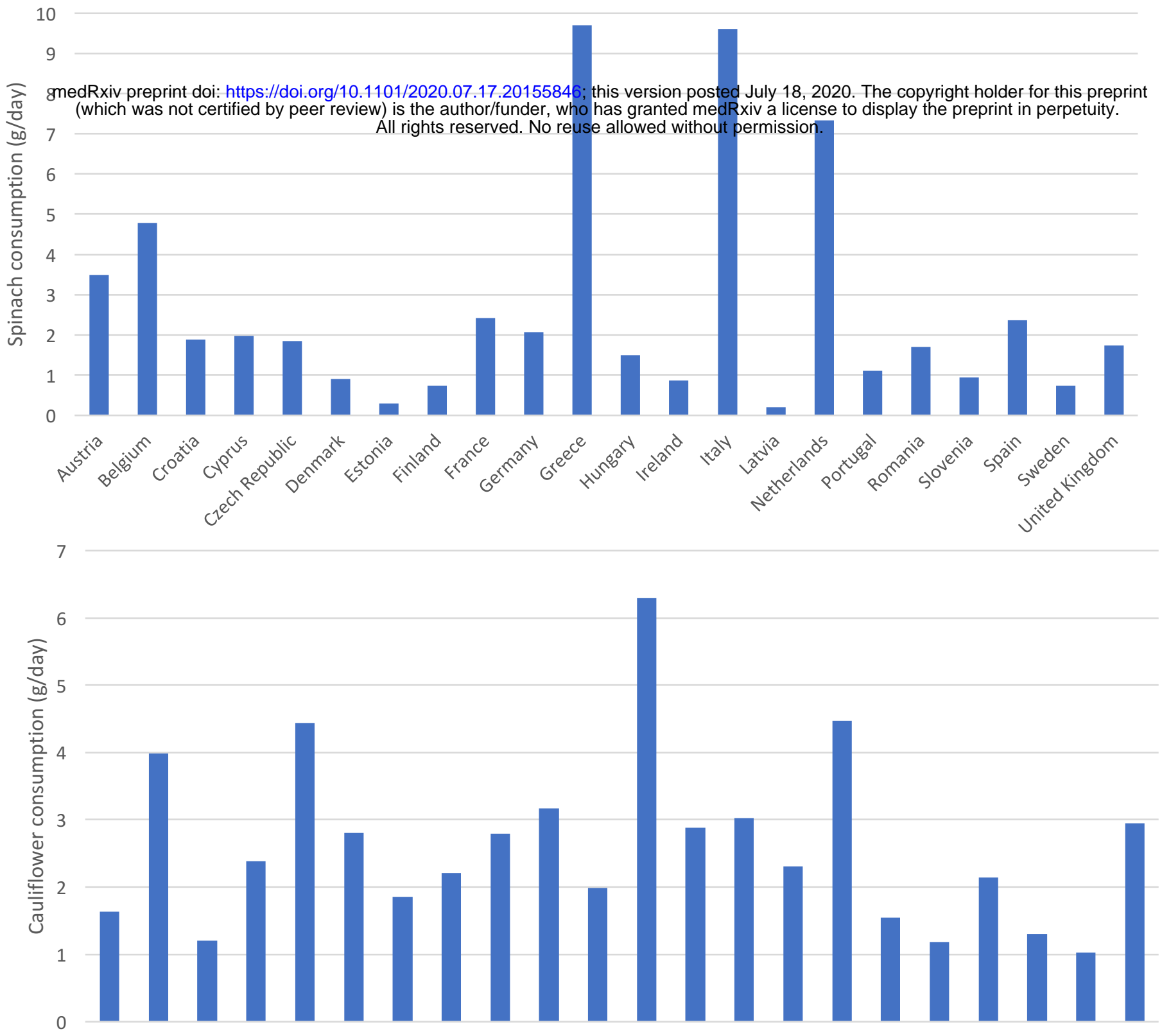

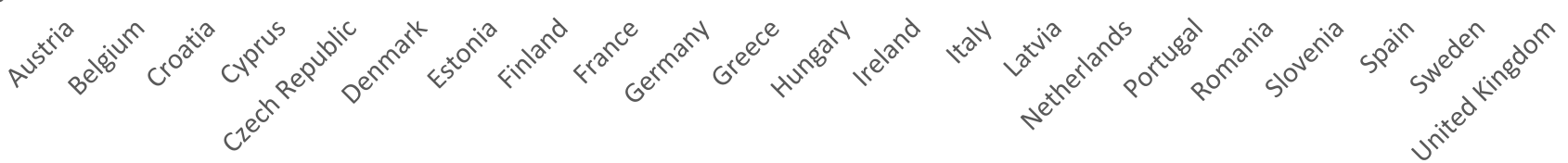

8

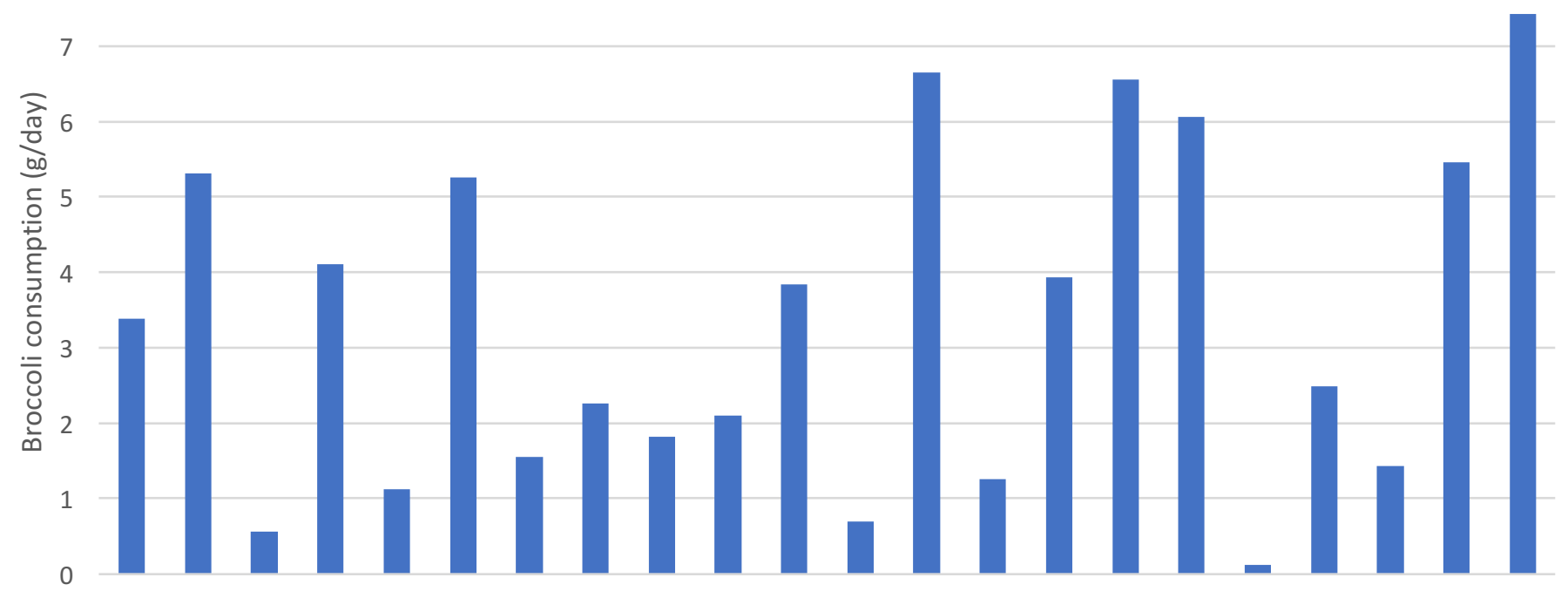

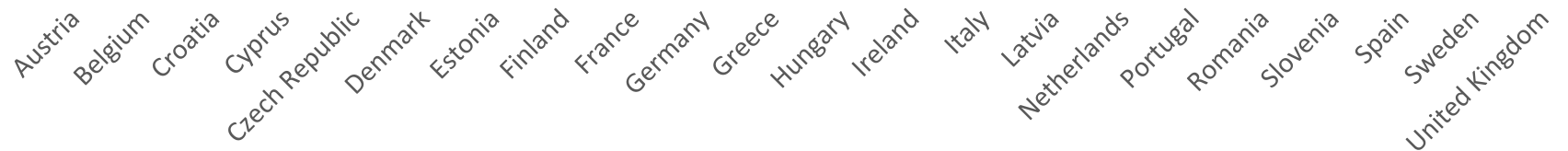


Fig 2
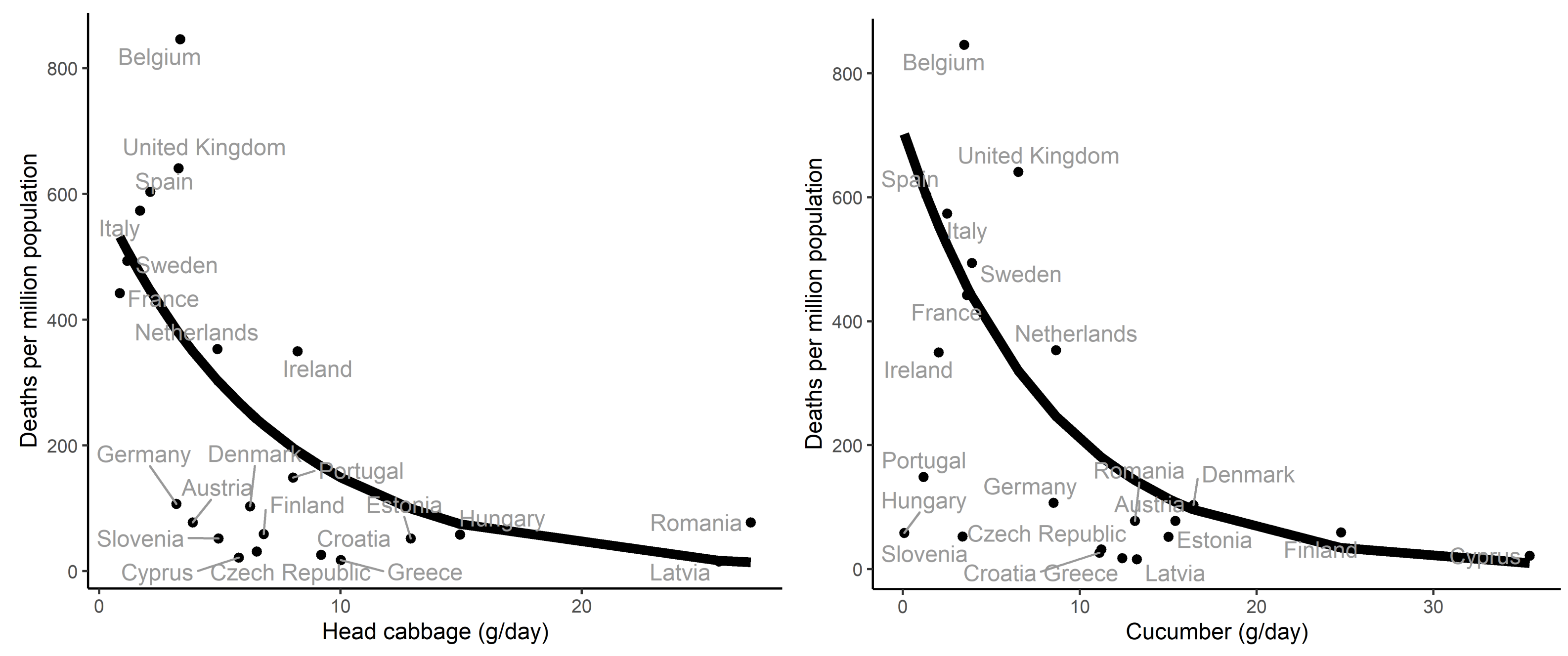